\title{
Tourism Object Development in Samosir Regency, Indonesia
}

\author{
Kariaman Sinaga $^{1}$, Suwardi Lubis ${ }^{2}$, Marlon Sihombing ${ }^{2}$, Ritha F Dalimunthe ${ }^{2}$ \\ ${ }^{1} P$ h.D Student in University of Sumatera Utara (USU), Medan, Indonesia \\ ${ }^{2}$ Lecturer in University of Sumatera Utara (USU), Medan, Indonesi \\ Email: elvipsonsinaga1975@gmail.com
}

\begin{abstract}
Potential tourism objects in an area, especially Samosir Regency, are very diverse, including natural beauty, history, culture that has its own charm. The tourism sector is one of the strategic sectors and the mainstay in Samosir Regency as a locomotive driving the improvement of the community's economy which contributes to the region's original income (PAD). The development of tourism objects in Samosir Regency is adjusted to the potentials of each community-based tourism object. The development of this tourism object is also stipulated by the Decree of the Samosir Regent Number 474 of 2017 concerning the Determination of Criteria and Classification of Tourism Objects in Samosir Regency which is carried out through the pattern of tourism development in ways or methods of work in optimizing the potential possessed. Criteria for tourism objects that have been regulated in tourism development policies can be used as a measure to develop tourism objects in Samosir Regency.
\end{abstract}

Keyword: tourism; Samosir Regency; tourism sector

\section{Introduction}

In connection with the implementation of tourism object development policies carried out in the Samosir District government there are two parts that will determine the success of the development of tourism objects. The division in question includes: implementation of policies carried out nationally and regionally in accordance with regional policies in the development of predetermined tourism objects. The quality of the linkages between national and regional programs is the basis for conducting programs as a follow-up for tourism development programs.

Dunn (2003) states that there are 5 (five) stages in the implementation of public policies ranging from setting the policy agenda (agenda setting) to policy evaluation (policy assessment) so that a policy can be implemented. To achieve the objectives at each stage of the policy, it is necessary to have a management process so that the goals that have been set can be achieved effectively and efficiently. The implementation of public policy requires a management process for effectiveness and efficiency in achieving objectives with the implementation of management functions. George R Terry in Supomo (2018: 27) states that management functions consist of planning, organizing, actuating and controlling. While Fayol in Supomo (2018: 27) stated that management functions consist of planning, organizing, commanding, coordinating and controlling. Furthermore, after the implementation of management functions is not necessarily the effectiveness and efficiency can work without empirical understanding. This is part of a policy evaluation that requires continuous improvement or improvement. Syafri (2012: 156) states that if the application of certain principles is not accompanied by empirical reality the results can cause a boomerang effect. 
Only with an in-depth empirical understanding can the implementation of the principles of implementation in the policy implementation process be carried out well. Furthermore, the implementation of policies in the development of tourist attractions in the Office of Tourism, Art and Culture of Samosir Regency is closely related to community support or participation. To be able to empower the community, it is necessary to have a process of understanding about a society. Understanding that is contextual (inclusive) of the condition of the community that requires adjustment or acceleration according to the implementation program of tourism development policies. Community involvement and private parties (stakeholders) ranging from planning, implementation to policy evaluation are the basis for achieving the success of a development program. The community is one of the important actors who play a direct role in the development of the tourism sector or subject / development actors. Therefore, a community empowerment model is needed so that the tourism object development program can run effectively and efficiently. The reason is that it is thought that the implementation of tourism development policies based on community empowerment is the government's priority so that the programs implemented can be in line with the community. As part of the policy, the monitoring aspect in policy implementation can be interpreted as part of policy implementation to be able to make further policy adjustments to aspects of human resources and natural resources by synergizing the government, the private sector and the community. Through the implementation of tourism area development policies in accordance with the regulations that have been established, the development of the region's distinctive potential in tourism is a factor that supports the increase in tourists because it has its own attraction. This effort needs to be carried out systematically to empower the potential of the region, especially the characteristics of the community to become a tourist attraction based on the development planning of an area based on community empowerment. Demolingo (2015) also gave the view that in the framework of developing tourism, the government must be involved in building a management tourism institution, improving human resources, building infrastructure from tourist facilities that are still lacking and forming a collaboration between the government and stakeholders including the community. Community empowerment is a part that must be a concern in the implementation of tourism development policies. The government must be oriented towards community empowerment in the development of tourism objects which include assesibility development, tourism facilities, attractions, and information and promotion. Community empowerment to participate in the development of tourist attractions cannot be directly obtained but must go through processes or stages. Community involvement in supporting the implementation of tourism development policies requires a process of community empowerment through understanding a community. The basis of community empowerment is done through an understanding of the social, cultural, and political conditions that exist in society so that the right way to empower them is obtained (Kartasasmita, 1997: 7).

Wasistiono (2003: 61) states that the process of community empowerment as a function of government is largely determined by two factors, namely exogenous factors and endogenous factors. Exogenous factors come from outside the community, especially in the form of government policies in carrying out the empowerment function by producing policies or programs related to community empowerment, while endogenous factors are factors within the community itself in the form of customary values, mental attitudes of the community itself. In fact, the policy of developing the tourist area that is run by the Samosir Regency Art and Culture Tourism Office has not empowered the community. This can be seen through an 
increase in tourist visits that are not as expected. Tourist visits are still seasonal or increase only at the beginning and end of the year.

\section{Theoretical Frame Work}

\subsection{Regional Development Management}

Regional development is carried out through development programs related to various aspects and with various multidisciplinary sciences in accordance with the conditions of a region. Regional development (regional development) has broad meaning and impact while at the same time not only paying attention to economic aspects, but involves institutional aspects (institutional settings), social (social settings), and ecological settings. These four aspects are one unit that is interrelated and integrated with each other (Sirojuzilam and Bahri, 2014).

Development of an area that maintains continuity also shows the opportunity of the community to be able to participate as a form of democracy. Community participation is related to planning and supervision so that the development can be achieved effectively and efficiently through an implementation process that is in accordance with the vision and mission that has been established (Nugroho, 2004). In the implementation of tourism development, the concepts of regional development must be related to the management of tourism development. The implementation of regional development must be in accordance with the planned plan. The planning in question includes planning at the local, regional, national and international levels. While the form is in the form of general planning and more specific planning such as planning the development of tourism objects. The development of an area is carried out in accordance with the demands in the life of the community. Tarigan (2004) states that the implementation of development in the area is an activity carried out in order to increase community income, increase employment and equal income. This is in accordance with the demands of competition at the global level through policies that can regulate the life of its citizens. In the context of regional development, organizations or government institutions in the region are required to be able to improve both human resources and natural resources in accordance with the stated goals. In carrying out the implementation of the policy, the organization can provide solutions as well as institutional responsibility for the development programs that are carried out. The importance of the organization in carrying out the management of tourism object organizations is needed so that a tourism development policy is successful. Local government organizations must have vision, values and courage.

Vision reflects the depth and breadth of understanding that makes it possible to detect and unfold the patterns of the organization run by a regional leader. Therefore district heads at the district level must be superior and visionary. Value or value is a belief or value system that is owned by the leader which is the basis of the direction and actions he chooses. Future organizations need a focus on the user, a willingness to make continuous improvement changes known as kaizen theory, and respect for human beings as the most important asset. Courage is the ability to make decisions based on scientific competence, skills. and moral integrity (Synder et.all, 1994 in Riant Nugroho: 2004). In the implementation of policy implementation is very much determined by the management of the implementation of a policy. For management success in carrying out a policy with strong leadership. A leader is required to be able to do creativity to be able to achieve goals effectively and efficiently. 
According to management experts Frederik W Taylor (1856-1915) and Hendry Fayol (1841-1925) the interrelationship of management with administration and leadership. Administration deals with activities through policy, management is focused on planned activities, and leadership is concerned with the art and arrangement of a leader .

\subsection{Community Empowerment}

Community empowerment means providing resources, opportunities, knowledge and skills to enhance the ability of the community to determine their own future and to participate and influence the lives of their communities (Ife and Tesoriero, 2008). This understanding shows that empowerment is not just helping the poor to become poor but can participate and influence the community. Other notions of empowerment according to Ife and Tesoriero are more directed at improving the ability of the community to be independent, able to control their future and can even influence others. Thus, community empowerment carried out has a direction to improve the quality of life of a community. Sardlow in Adi (2008) said essentially the notion of empowering its scope is how individuals, groups or communities try to control their own lives and seek to shape the future according to their wishes. Adi (2008) said empowerment goals and targets could be different, for example in the fields of economics, education or health. Empowerment can also vary in development so that empowerment in a field can be different from other fields. This requires understanding both individually and in groups known as the identification process. In accordance with the context of life in society, the field of community empowerment has a very broad scope. To empower it, it needs to be adjusted to the area that is the focus of community empowerment. This is in line with the needs in the community and changes both locally, regionally, nationally and internationally. Soetomo (2006) explains that community empowerment or development is a planned social change, both in the economic, technological, social and political fields. Community development in a broad sense can also mean a development process that focuses more on the human or community aspects. In a narrow sense, community development means changes in social planning in a particular field. Empowerment is also defined as a process by which people become strong enough to be able to participate, share control, influence events and institutions that affect their lives. Empowerment emphasizes that people acquire sufficient skills, knowledge and power to influence their lives and the lives of others that concern them (Parson in Suharto, 2004). Empowerment is called a program when viewed from the stages of activities undertaken to achieve goals and requires a certain period of time for its achievement. Empowerment is seen as a process when empowerment continues throughout the human age and does not stop at a time. Likewise in the community, the empowerment process will continue as long as the community remains and continues to empower themselves. The stage of community empowerment itself, according to Subejo and Supriyanto (2004) starts from the site selection process to the independence of the community. In detail each stage is as follows:

1. Location Selection Phase;

2. Community Empowerment Socialization Phase;

3. The community empowerment process stage, which is divided into several activities:

a. Situation studies to develop participatory efforts

b. Group development

c. Preparation of plans and implementation of activities

d. Participatory monitoring and evaluation

4. Community Self-Reliance Stage. 
Suharto (2006) said empowerment refers to the ability of people, especially vulnerable and weak groups so that they have the power or ability in:

1. Meet their basic needs so they have freedom

2. Reaching productive resources that enable them to increase their income and obtain the goods and services needed

3. Participate in the development process and decisions that affect them.

For this reason, indicators of community empowerment that are used to determine operational focus and objectives of empowerment are:

1. Freedom of mobility

2. Ability to buy small commodities

3. Ability to buy large commodities

4. Engage in making household and community decisions

5. Relative freedom from family domination

6. Legal and political awareness

7. Engagement in campaigns and protests

8. Economic security and contribution to the family (Suharto, 2006).

From these indicators, empowerment in the perspective of social work has levels, namely:

1. From being helpless to being powerless

2. After empowering then strengthen

3. After strengthening and developing.

Empowerment is defined as an empowering condition in the economic, social and cultural fields. Empowerment carried out in the process of development or improvement of the management of tourism objects carried out in rural areas is carried out through the village community empowerment approach. Law Number 6 of 2014 concerning Villages Article 1 Paragraph 12, explains that rural community empowerment is an effort to develop independence and prosperity the community by increasing knowledge, attitudes, skills, behaviors, abilities, awareness, and utilizing resources through the establishment of policies, programs, activities and mentoring in accordance with the essence of the problem and the priority needs of the village community.

\subsection{Policy Implementation}

Policy implementation is the most decisive part of the success of a public policy. Failure in policy implementation can have a very bad impact because it relates to public trust and costs incurred from the people. As part of the policy, policy implementation is the most crucial stage after the establishment of a policy through the political process at the regional and national levels. Policies that have been established both nationally and regionally will require explanatory policies or derivatives in the form of development programs. The policy in question can be in the form of rules aimed at the public interest rather than the elite or a group of people or a group of people. This really requires the ability of the local government to make adjustments (cascading) in translating development plans. Law Number 23 of 2014 concerning Regional Government provides opportunities for regions in the form of greater authority to manage development independently and democratically. As an autonomous region, the authority granted based on the principle of decentralization in the form of broad, real and responsible autonomy covers all fields of government except in the fields of politics, defense, justice, monetary and religion. With regard to operational implementation, a policy 
has differences according to the level of a policy that will be implemented. Riant Nugroho (2004: 159) states that public policy in the form of laws or regional regulations is a type of public policy that requires explanatory public policy or is often termed as implementing regulations. While some public policies that can be directly operational include: Presidential Decree (Presidential Decree), Inpres, Ministerial Decree, Decree of the Regional Head, and Decree of the Head of Service. The series of policy implementation can be seen in public sector management which includes the determination of vision, mission, plans, strategies, programs, projects, activities and feedback. Stages carried out to answer problems in accordance with the management context of an organization. In a simple sense it can be divided into planning, implementing, and evaluating. Policy implementation is carried out through the management process after the establishment of a policy which includes the stages of organizing, stages of leadership, and stages of control. From the side of the government as the holder of power, the implementation stage can be seen through the structure or strategy applied, the institutions formed, the operationalization, and the procedures used. At the organizing stage, the organization is designed, division of labor, coordination, recruitment, placement of human resources, rights and obligations, delegation and capacity building of human resources. The mobilization or leadership stage includes: leadership effectiveness, motivation, ethics, quality, team collaboration, organizational communication, and negotiation. Policy implementation is part of public policy which consists of: policy formulation, policy implementation, and policy evaluation. This is done so that the target communities can live and thrive through service assignments, development tasks, and empowerment tasks. Service duties are public services to the community without discrimination and are free. The task of development is to improve the economic welfare of the community and the task of empowerment is the role of making every citizen able to improve the quality of humanity and society. (Nugroho: 2004). This is in line with the concept of community empowerment that is carried out through identity recognition, strengthening and protection through development or development programs that are carried out. Through these stages will get results from the improvement of the community after going through the stages of empowerment. To achieve the series of stages of the activity, it is necessary to have cooperation (synergy) between the government, the private sector and the community. Community empowerment is an effort to raise the values of the life of a society or the quality of humanity and society. The award referred to is social participation (civil society) and strong development (democration) in addition to meeting basic needs.

Community empowerment is a way to provide opportunities for the community to be able to fulfill their own needs so that they have competitiveness with other communities both regionally, nationally and internationally in accordance with the development context. Furthermore, the importance of empowering requires policies from the government to improve the quality of the community or strengthen the program being implemented. In the strategic level there are 3 (three) references that must be considered with the policies implemented in empowering the community, namely: referring to goals, referring to the context of challenges, and referring to the resources they have (Riant Nugroho: 2004).

\section{Discussion}

Potential tourism objects in an area, especially Samosir Regency, are very diverse, including natural beauty, history, culture that has its own charm. This diverse potential must 
also be supported by the hospitality of the population and the readiness of the facilities and infrastructure, which are the main factors in the development of tourism objects. In general, the natural beauty possessed by the Samosir area is still natural or natural which is also supported by the culture of the community and the friendly nature that is still inherent in the lives of local people. So, as for the potential possessed by an area that outperforms the tourism sector, among others are the natural potential associated with natural scenery, the beauty of the coast and the sea and also the hills and mountains. While the next potential is the socio-cultural potential consisting of the culture and customs of the community. These potentials are also the reason for the development of tourism objects in Samosir Regency. The development of this tourism object was carried out by implementing the Decree of the Samosir Regent Number 474 of 2017 concerning the Determination of Criteria and Classification of Tourism Objects in Samosir Regency. The steps of developing tourism objects carried out by the Samosir Regency Tourism Office include:

a. Utilizing strategic positions and the potential advantages of natural beauty and local culture.

b. Improving the provision of tourism supporting infrastructure, whether in the form of transportation networks, clean water, electricity, telecommunications, accommodation and others to increase the attractiveness of tourism objects, both for potential investors and tourists.

c. Integrating tourism development patterns by creating a network of tourist routes to optimize existing ecotourism potentials while extending the length of stay of tourists.

d. Directing local communities to actively participate and not only act as objects of tourism development.

e. Conducting events and promotion of tourism to attract tourists to visit.

f. Inviting investors to invest in developing the tourism industry.

The tourism sector is one of the strategic sectors and the mainstay in Samosir Regency as a locomotive driving the improvement of the community's economy which contributes to the region's original income (PAD). Based on Samosir District RPJMD, that the magnitude of the contribution of this sector really depends on the number of tourist visits, the availability of lodging and attractions in Samosir Regency, namely

a. Tourist Visits

The number of tourist visits both domestic tourists and foreign tourists increases from year to year. The increasing number of tourists to Samosir Regency will increase PAD from the tourism sector.

Table 1. Number of Tourist Visits in. Samosir Regency Year 2010 - 2014

\begin{tabular}{|c|c|c|c|}
\hline \multicolumn{4}{|c|}{ Number of Tourist Visits } \\
\hline Year & Archipelago Tourists & Foreign tourists & Total \\
\hline 2010 & 94.629 & 20.913 & 115.542 \\
\hline 2011 & 109.897 & 22.732 & 132.629 \\
\hline 2012 & 119.530 & 25.297 & 144.827 \\
\hline 2013 & 124.117 & 25.662 & 149.779 \\
\hline 2014 & 140.637 & 30.450 & 171.087 \\
\hline
\end{tabular}

Source: Samosir in 2015 Figures

b. Lodging Availability 
Table 2. Types, Classes and Amounts of Samosir Regency Lodging / Hotels in 2014

\begin{tabular}{|c|c|c|c|c|}
\hline \multirow{2}{*}{ No } & Types of Lodging / & \multicolumn{3}{|c|}{ Year 2014 } \\
\cline { 3 - 5 } & Hotels & total Hotel & Total of rooms & Total of beds \\
\hline 1 & 5 star hotel & 0 & 0 & 0 \\
\hline 2 & 4-star hotel & 0 & 0 & 0 \\
\hline 3 & 3-star hotel & 0 & 0 & 0 \\
\hline 4 & 2-star hotel & 5 & 354 & 165 \\
\hline 5 & 1 Star Hotel & 1 & 51 & 2128 \\
\hline 6 & $\begin{array}{c}\text { Non Star Hotels (budget } \\
\text { hotels and other } \\
\text { accommodations }\end{array}$ & 76 & 1301 & 2920 \\
\hline
\end{tabular}

Source: Samosir in 2015 Figures

c. Tourist Destinations

Table 3. Samosir Regency Tourism Destinations

\begin{tabular}{|c|c|c|c|}
\hline No & $\begin{array}{c}\text { Locations of Per District } \\
\text { Attractions }\end{array}$ & Tourism site & Types of Attractions \\
\hline 1 & PANGURURAN & $\begin{array}{ll}\text { a. } & \text { Terusan Tano Ponggol } \\
\text { b. Pemandian Air Panas di Aek } \\
\\
\text { Rangat } \\
\text { c. Monumen Perjuangan Liberty } \\
\text { Malau } \\
\text { d. Komunitas Tenus Ulos Batak Huta } \\
\text { Raja Lumban Suhisuhi } \\
\text { e. Open Stage Pasar Pangururan } \\
\text { f. Pasanggrahan Pangururan } \\
\text { g. Obyek Wisata Boru Sinaetang } \\
\text { h. Pantai Pasir Putih Huta Balon } \\
\text { Parbaba } \\
\text { i. Pantai Pasir Putih Lumban Manik }\end{array}$ & $\begin{array}{l}\text { Historical Tourism } \\
\text { Water / Recreation } \\
\text { Tourism } \\
\text { Historical Tourism } \\
\text { Culture tour } \\
\text { Culture tour } \\
\text { Historical Tourism } \\
\text { Culture tour } \\
\text { Water / Recreation } \\
\text { Tourism } \\
\text { Water / Recreation } \\
\text { Tourism }\end{array}$ \\
\hline 2 & SIMANINDO & $\begin{array}{l}\text { a. Makam Tua Raja Sidabutar } \\
\text { b. Kawasan Tuk-tuk Siadong } \\
\text { c. Museum Tomok } \\
\text { d. Tuk-tuk Siasu } \\
\text { e. Museum Huta Bolon } \\
\text { f. Pulo Malau } \\
\text { g. Museum Gok Asi Simanindo } \\
\text { h. Areal Lomba Paralayang Siulak } \\
\text { Hosa } \\
\text { i. Kawasan Arboretum Aek Natonang } \\
\text { j. Gua Lontung } \\
\text { k. Sipokki } \\
\text { l. Tanjungan } \\
\text { m. Raut Bosi } \\
\text { n. Simanindo Parbaba } \\
\text { o. Gua Alam Sangkal } \\
\text { p. Pertunjukan Sigale-gale }\end{array}$ & $\begin{array}{l}\text { Historical Tourism } \\
\text { Natural tourism } \\
\text { Historical Tourism } \\
\text { Historical / Cultural } \\
\text { Tourism Culture } \\
\text { Tour Natural } \\
\text { Culture tourism } \\
\text { Recreational Tourism } \\
\text { Natural tourism } \\
\text { Guo Natural } \\
\text { tourism } \\
\text { Natural tourism } \\
\text { Natural tourism } \\
\text { Historical Tourism } \\
\text { Cave Tourism } \\
\text { Historical Tourism } \\
\end{array}$ \\
\hline
\end{tabular}


Budapest International Research and Critics Institute-Journal (BIRCI-Journal)

Volume I, No 3, October 2018, Page: 91-104

e-ISSN: 2615-3076(Online), p-ISSN: 2615-1715(Print)

www.birci-journal.com

emails; birci.journal@gmail.com

birci.journal.org@gmail.com

\begin{tabular}{|c|c|c|c|}
\hline & & $\begin{array}{ll}\text { q. Perumahan Batak } \\
\text { r. Batu Kursi Parsidangan Huta } \\
\text { Siallagan } \\
\text { s. Bukit Beta Kite Internasional } \\
\text { t. Batu Marhosa } \\
\text { u. Gedung Kesenian Tuk-tuk Siadong } \\
\text { v. Situs Pagar Batu (Liang } \\
\text { Marlangkup, Botean, Parit } \\
\text { Debata, Losung Simarlage-lage } \\
\text { Sitolu Mata/Losung Marante } \\
\text { w. Open Stage Tuk-tuk Siadong }\end{array}$ & $\begin{array}{l}\text { Culture tour } \\
\text { Natural tourism } \\
\text { Natural tourism } \\
\text { Natural tourism } \\
\text { Natural tourism } \\
\text { Culture tourism }\end{array}$ \\
\hline 3 & $\begin{array}{c}\text { SIANJUR MULA- } \\
\text { MULA }\end{array}$ & $\begin{array}{l}\text { a. } \text { Gunung Pusuk Buhit } \\
\text { b. Pemandian Aek Sipitu Dai } \\
\text { c. Perkampungan Asli Huta Siraja } \\
\text { Batak } \\
\text { d. Perkampungan Sigulatti } \\
\text { e. Aek Si Boru Pareme } \\
\text { f. Batu Hobbon } \\
\text { g. Batu Holbung } \\
\text { h. Pulau Tulas } \\
\text { i. Air Terjun Hadabuan Nasogo } \\
\text { j. Aek Boras } \\
\text { k. Batu Pargasipan } \\
\text { l. Batu Parhusipan } \\
\text { m. Batu Nanggar } \\
\text { n. Batu Sawan } \\
\text { o. Rumah Parsaktian Guru Tatea } \\
\text { Bulan }\end{array}$ & \begin{tabular}{l}
\multicolumn{1}{c}{ Cuistorical } \\
Tourism Wateral / Culture \\
Tourism \\
Culture tour \\
Culture tour \\
Water / Culture Tourism/ \\
Nature Culture Tourism \\
Nature / Culture Tourism \\
Recreational Tourism \\
Nature and Water \\
Tourism \\
Water recreation \\
Culture tour \\
Culture tour \\
Culture tour \\
Nature / Culture Tourism \\
Culture tour
\end{tabular} \\
\hline 4 & RONGGUR NIHUTA & $\begin{array}{ll}\text { a. Aek Liang } \\
\text { b. Gua Sidam-dam } \\
\text { c. Batu Simalliting } \\
\text { d. Danau Sidihoni } \\
\text { e. Batu Hitam } \\
\text { f. Sea ni Tano } \\
\text { g. Aek Sipale Onggang } \\
\text { h. Kawasan Wisata Tirta Pea } \\
\text { Porogan }\end{array}$ & $\begin{array}{l}\text { Water recreation } \\
\text { Cave Tourism } \\
\text { Natural tourism } \\
\text { Recreational Tourism } \\
\text { Natural tourism } \\
\text { Water / Nature Tourism } \\
\text { Water recreation Water }\end{array}$ \\
\hline 5 & HARIAN BOHO & $\begin{array}{l}\text { a. Menara Pandang Tele } \\
\text { b. Partuko Naginjang } \\
\text { c. Janji Martahan } \\
\text { d. Air Terjun Sampuran Efrata } \\
\text { e. Mata Air dan Pohon Pokki } \\
\text { f. Gua Parmonangan } \\
\text { g. Kampung Harimau Situmeang } \\
\text { h. Ulu Darat } \\
\text { i. Janji Motugo } \\
\text { j. Hutan Flora Anggrek } \\
\text { k. Rumah Adat } \\
\text { l. Hutan Limbong } \\
\text { m. Rumah Adat Sagala }\end{array}$ & $\begin{array}{l}\text { PanoramaTourism } \\
\text { Natural tourism } \\
\text { Natural tourism } \\
\text { Natural tourism } \\
\text { Natural tourism } \\
\text { Cave Tourism } \\
\text { Historical Tourism } \\
\\
\text { Natural tourism } \\
\text { Natural tourism } \\
\text { Natural tourism } \\
\text { Culture tour } \\
\text { Natural tourism }\end{array}$ \\
\hline
\end{tabular}


Budapest International Research and Critics Institute-Journal (BIRCI-Journal)

Volume I, No 3, October 2018, Page: 91-104

e-ISSN: 2615-3076(Online), p-ISSN: 2615-1715(Print)

www.birci-journal.com

emails; birci.journal@gmail.com

birci.journal.org@gmail.com

\begin{tabular}{|c|c|c|c|}
\hline & & & Culture tour \\
\hline 6 & SITIO-TIO & $\begin{array}{l}\text { a. Mata Air/Mual Datu Parngongo } \\
\text { b. Gua Datu Parngongo } \\
\text { c. Parmandian Boru Saroding di } \\
\text { Sabulan } \\
\text { d. Patung Raja si Lontung }\end{array}$ & $\begin{array}{l}\text { Water / Culture Tourism } \\
\text { TourismWater / Culture } \\
\text { Tourism } \\
\text { Historical / Cultural } \\
\text { Tourism }\end{array}$ \\
\hline 7 & PALIPI & $\begin{array}{l}\text { a. Goa Bunda Maria } \\
\text { b. Piso Somalim } \\
\text { c. Batu Rantai } \\
\text { d. Pemandian Air Panas Simbolon } \\
\text { e. Martua Limang }\end{array}$ & $\begin{array}{l}\text { Spiritual Tourism } \\
\text { Historical Tourism } \\
\text { Natural tourism } \\
\text { Water recreation } \\
\\
\text { Historical Tourism } \\
\end{array}$ \\
\hline 8 & NAINGGOLAN & $\begin{array}{l}\text { a. Pantai Pasir Putih } \\
\text { b. Batu Guru } \\
\text { c. Rumah Parsaktian } \\
\text { d. Hotel Golat } \\
\text { e. Atraksi Budaya dan Agama } \\
\text { f. Pananggangan } \\
\text { g. Polhang } \\
\text { h. Boru Simenak-menak } \\
\text { i. Sidabasa }\end{array}$ & $\begin{array}{l}\text { Water Tourism, } \\
\text { Recreation Water / } \\
\text { Recreation Tourism } \\
\text { Natural tourism } \\
\text { Historical Tourism } \\
\text { Culture tour } \\
\text { Historical Tourism } \\
\text { Natural tourism } \\
\text { Natural tourism } \\
\text { Historical Tourism } \\
\end{array}$ \\
\hline 9 & ONAN RUNGGU & $\begin{array}{l}\text { a. Kawasan Wisata Remaja Lagundi } \\
\text { Sitamiang } \\
\text { b. Pantai Pasir Putih Sukkean } \\
\text { c. Hariara Nabolon/Pohon Besar } \\
\text { Sukkean } \\
\text { d. Tambun Surlau } \\
\text { e. Mual Siraja Sonang di Pakpahan }\end{array}$ & $\begin{array}{l}\text { Nature / Water / } \\
\text { Recreation Tourism } \\
\text { Water / Recreation } \\
\text { TourismNatural tourism } \\
\text { Historical Tourism } \\
\text { Culture tour }\end{array}$ \\
\hline
\end{tabular}

Source: Samosir District RPJMD 2016-2021

Based on the data above, that the development of tourism in an area that will bring many benefits to the community, namely economically, socially and culturally. The division of tourism objects above is one of the reasons to develop the tourism potential of Samosir Regency which needs to be explored, developed, managed, utilized and protected in an efficient, integrated, planned and sustainable manner. In accordance with Samosir Regent Decree Number 474 of 2017 concerning Determination of Criteria and Classification of Tourist Objects in Samosir Regency, Third, Fourth and Fifth Chapter, there is a division or grouping of tourism objects according to predetermined criteria, namely:

a. Featured Attractions, include:

1) Old Tomb of King Sidabutar in Tomok Parsaoran Village, Simanindo District

2) Siadong Tuk-tuk area in Tuk-tuk Siadong Village, Simanindo District

3) Stone Parsidangan Chair in Siallagan Pindaraya Village, Simanindo District

4) Huta Bolon Museum in Simanindo Village, Simanindo District

5) Parbaba White Sand Beach in Huta Bolon Village, Pangururan District

6) Aek Rangat Pangururan in Siogung-ogung Village, Pangururan District

7) View Tower Tele in Partungko Naginjang Village, Daily Subdistrict

8) Aek Sipitu Dai in Aek Sipitu Dai Village, Sianjur District First 
9) Batu Sawan in Sarimarrihit Village, Sianjur District

10) Efrata Waterfall in Sosor Dolok Village, Harian Harian

11) Naisogop Waterfall in Sianjur Village

b. Priority Tourist Objects, including:

1) Batu Hobon in Sari Marrihit Village, Sianjur District

2) Lake Sidihoni in Sabungan Nihuta Village, Ronggur Nihuta District

3) Pantai Indah Situngkir in Situngkir Village, Pangururan District

4) Sibolay Beach in Simanindo Village, Simanindo District

5) Batu Marhosa in Parmonangan Village, Simanindo District

6) Pangururan Inkulturative Catholic Church in Pardomuan I Village, Pangururan District

7) Pondok Remaja Lagundi in Sitamiang Village, Onan Runggu Subdistrict

8) Siraja Batak Village in Sianjur Village Initially, Sinajur Subdistrict

9) Aek Natonang in Tanjungan Village, Simanindo District

c. Stubs, including:

1) Batu Hoda Beach in Cinta Dame Village, Simanindo District

2) Pangribuan Waterfall in Pardomuan Nauli Village, Palipi District

3) Graves on the Tree of Tomok Village, Simanindo District

4) Parsaktian Lumban Raja Desa House, Onan Runggu Subdistrict

5) Mual Boru Saroding in Sabulan Village, Sitiotio District

6) Climbing Pusuk Buhit Mountain in Sianjur District First

7) Pea Porohan in Salaon Toba Village, Ronggur Nihuta District

8) Pea Roba in Sihusapi Village, Simanindo District

9) Bulu Turak in Cinta Dame Village, Simanindo District

10) Aek Sipalionggang in Ronggur Nihuta Village, Ronggur District NIhuta

11) Maranak Daily in Urat II Village, Palipi District

12) Sipinggan White Sand Beach in Sipinggan Village and Sipinggan Lumban Siantar Village, Nainggolan District

13) Hariara Bolon Sukkean in Tambun Sukkean Village, Onan Runggu District

14) Aek Rangat Pitu Batu in Rianiate Village, Pangururan District

15) Take of Paragliding Area in Sihulak Hosa, Simanindo District

16) Langat Beach in Simanindo Village, Simanindo District

17) Toga Sinaga Monument in Urat II Village, Palipi District

18) Dolok Holbung Sipege in Hariara Pohan Village, Kecamatan Harian

19) Liang Sipagu in Sangkal Village, Simanindo District

20) Sinatapan Prayer Tower at Aek Rangat Pangururan District

\section{Conclusion}

The development of tourism objects in Samosir Regency is adjusted to the potentials of each community-based tourism object. The development of this tourism object is also stipulated by the Decree of the Samosir Regent Number 474 of 2017 concerning the Determination of Criteria and Classification of Tourism Objects in Samosir Regency which is carried out through the pattern of tourism development in ways or methods of work in 
optimizing the potential possessed. Criteria for tourism objects that have been regulated in tourism development policies can be used as a measure to develop tourism objects in Samosir Regency.

\section{References}

Abidin, Said Zainal. 2006. Kebijakan Publik. Jakarta: Suara Bebas.

Adi, Isbandi Rukminto. 2008. Intervensi Komunitas; Pengembangan Masyarakat Sebagai Upaya Pemberdayaan Masyarakat. Rajawali Press. Jakarta.

Airey, David. 2015. Developments in Understanding Tourism Policy. Tourism Review Journal Vol. 70, No. 4, pp. 18-44 ISSN: 1660-5373

Akroush, Mamoun N. Et.al. 2016. Tourism Service Quality and Destination Loyalty-The Mediating Role of Destination Image from International Tourist's Perspectives. Tourism Review Journal Vol. 71, No. 1, pp. 18-44 ISSN: 1660-5373

Andri. 2006. Perspektif Pembangunan Wilayah Pedesaan. Jurnal Inovasi, Vol. 6 (18).

Basrowi dan Suwandi, 2008. Memahami Penelitian Kualitatif, Rineka Cipta: Jakarta

Creswell, Jhon W. 2010. Research Design Pendekatan Kualitatif, Kuantitatif dan Mixed. Pustaka Pelajar: Yogyakarta

Demolingo, Ramang Husin. 2015. Strategi Pengembangan Destinasi Wisata Desa Bongo Kabupaten Gorontalo. Jurnal Manajemen Pariwisata, Volume 1, No. 2, Januari 2015, ISSN: 2406-9116

Dinas Pariwisata, Seni Dan Budaya Kabupaten Samosir, Tahun 2015

Dunn, William N. 2003. Pengantar Analisis Kebijakan Publik. Yogyakarta: Gadjah Mada University Press.

Grindle, Merille S (ed.).1980,Politics and policy Implementtion in the world, New Jersey: Princeton University Press.

Ife, Jim \& Tesorieno, Frank. 2008. Community Development; Alternatif Pengembangan Masyarakat di Era Globalisasi. Pustaka Pelajar. Yogyakarta.

Jupir, Maksimilianus Maris. 2013. Implementasi Kebijakn Pariwisata Berbasis Kearifan Lokal (Studi di Kabupaten Manggarai Barat). Journal of Indonesian Tourism and Development Studies, Vol. 1, No. 1, Januari 2013 E-ISSN: 2338-1647

Kartassmita, Ginandjar, Pembangunan Untuk Rakyat-Memadukan Pertumbuhan dan Pemerataan.Penerbit PT.Pustaka Cidesindo, Jakarta

Lestari, Susi. 2009. Pengembangan Desa Wisata dalam Upaya Pemberdayaan Masyarakat (Studi di Desa Wisata Kembang Arum, Sleman). Program Studi Sosiologi Fakultas Ilmu Sosial dan Humaniora Universitas Islam Negeri Sunan Kalijaga; Yogyakarta.

Lubis, Solly. 2007. Kebijakan Publik. Bandung: Mandar Maju

Lumbanraja, Victor.Differensiasi Perkembangan Objek Wisata.Journal Fakultas Geografi UGM dan Asosiasi Geografi Indonesia, Vol.44, No.2.Desember 2012 (150-160) ISSN 0024-9521

Miles,M.B, Huberman,A.M, dan Saldana,J. 2014. Qualitative Data Analysis, A Methods Sourcebook, Edition 3. USA: Sage Publications. Terjemahan Tjetjep Rohindi Rohidi, UI-Press

Mulyana, Bedi. 2011. Pengembangan Kota Bogor sebagai Destinasi Pariwisata Internasional. Jurnal Ilmiah Pariwisata Vol. 2, No. 1, September 2012 
Nalayani, Ni Nyoman Ayu Hari. 2016. Evaluasi dan Strategi Pengembangan Desa Wisata di Kabupaten Badung, Bali. Jurnal Manajemen Pariwisata, Volume 2, No. 1, Januari 2016, ISSN: 2406-9116.

Ningrum, Indriani Rahma. 2014. Analisis Peran Modal Sosial terhadap Pemberdayaan Masyarakat dalam Melestarikan Kebudayaan dan Pengembangan Sektor Pariwisata (di Desa Padang Tegal, Kecamatan Ubud, Kabupaten Gianyar, Bali). Jurusan Ilmu Ekonomi Fakultas Ekonomi dan Bisnis Universitas Brawijaya; Malang

Nugroho, Iwan dan Rokhmin Dahuri. 2012. Pembangunan Wilayah; Perspektif Ekonomi, Sosial, dan Lingkungan. LP3ES. Jakarta.

Nugroho, Riant. 2004. Public Policy. Pt. Elex Media Komputindo; Jakarta

Peng, Kang-Lin dan Pearcl M. C. Lin., 2016. Social Entrepreneurs: Innovating Rural Tourism Through The Activism of Service Science. International Journal of Contemporary Hospitality Management Vol. 28, No. 6, 2016 pp.1225-1244

Peraturan Pemerintah Nomor 50 Tahun 2011 Tentang RIPPARNAS 2010 - 2015

Peraturan Daerah Kabupaten Samosir Tentang Rencana Pembangunan Jangka

Menengah Daerah (RPJMD) 2016-2021

Rustiadi, Ernan, Lokakarya Otonomi Daerah, Study Club Jakarta Media Center, 2001

Surat Keputusan Bupati Samosir Nomor 474 Tahun 2017 Tentang Klasifikasi Objek Wisata di Kabupaten Samosir

Sirojuzilam. 2008. Disparitas Ekonomi \& Perencanaan Regional. Pustaka Bangsa Press. Medan.

Sirojuzilam dan Syaiful Bahri. 2014. Pembangunan Ekonomi Wilayah Sumatera Utara. USU Press. Medan.

Sjafrizal. 2014. Perencanaan Pembangunan Daerah dalam Era Otonomi. Raja Grafindo Persada. Jakarta.

Soedarso et al.2015.Strategi Pengembangan Pariwisata Daerah dan Pemberdayaan Masyarakat di Parigi Moutong,Jurnal: Masyarakat, Kebudayaan dan Politik Vol.29, No.3,Tahun 2016, hal 159-166.

Soetomo. 2006. Strategi-strategi Pembangunan Masyarakat. Pustaka Pelajar.

Yogyakarta.

Suharsono, A.G. 2010. Analisis Kebijakan Publik (Konsep, Teori dan Aplikasi).

Yogyakarta: Penerbit Pustaka Pelajar.

Subejo dan Supriyanto. 2004. Metodologi Pendekatan Pemberdayaan Masyarakat, Dewan Mahasiswa Fakultas Pertanian UGM. Yogyakarta.

Suharto, Edi. 2004. Pendekatan Pekerjaan Sosial Dalam Pemberdayaan Masyarakat Miskin: Konsep, Indikator dan Strategi. Malang.

Suwantoro, Gamal. 1997. Dasar-dasar Pariwisata. Penerbit Andi; Yogyakarta.

Syafri, Wirman. 2012. Studi Tentang Administrasi Publik; Penerbit Erlangga.Jatinangor.

Syaodih, Ernady.2015.Manajemen Pembangunan Kabupaten dan Kota.PT.Refika Aditama. Bandung

Tangkilisan, Hesel Nogi S. 2003. Implementasi Kebijakan Publik. Lukman Offfiset dan Yayasan Pembaruan Administrasi Publik Indonesia. Yogyakarta.

Tarigan, Robinson. 2006. Perencanaan Pembangunan Wilayah (Edisi Revisi). PT Bumi Aksara. Jakarta.

Undang-Undan Republik Indonesia Nomor 6 Tahun 2004 Tentang Desa

Undang-Undan Republik Indonesia Nomor 23 Tahun 2014 Tentang Pemerintahan Daerah 
Budapest International Research and Critics Institute-Journal (BIRCI-Journal) Volume I, No 3, October 2018, Page: 91-104 e-ISSN: 2615-3076(Online), p-ISSN: 2615-1715(Print)

www.birci-journal.com emails; birci.journal@gmail.com birci.journal.org@gmail.com

Undang-undang Nomor 25 Tahun 2004 Tentang Sistem Perencanaan Pembangunan Nasional Widjajanti, Kesi. 2011.Model Pemberdayaan Masyarakat. Jurnal Ekonomi Pembangunan 12: 26, Jakarta.

Wasistiono, Sadu.2003.Kapita Selekta Manajemen Pemerintahan Daerah.Fokus Media, Bandung

Wahyudi, Agustinus Sri. 2006. Manajemen Strategi: Kebijakan dan Implementasi. Mandar Maju, Bandung

Yoeti, H. O. A., 1997. Pengantar Ilmu Pariwisata, Penerbit Angkasa; Bandung 